\title{
Prevalence and Distribution of Congenitally Missing Teeth in Patients Visiting the Department of Pediatric Dentistry of Chonbuk National University Hospital
}

\author{
Hyunsoon Jeon, Yeonmi Yang, Byeongju Baik, Jaegon Kim \\ Department of Pediatric Dentistry and Institute of Oral Bioscience, School of Dentistry, Chonbuk National University
}

\section{Abstract}

The goal of this study was to analyze prevalence and distribution of congenitally missing teeth in 3302 patients from 7 to 15 years old, who had visited and taken panoramic radiographs at the Department of Pediatric Dentistry, from January 2008 to December 2012.

The prevalence of hypodontia in the males (5.9\%) was slightly higher than in the females $(4.7 \%)$. In the affected patients, the mean number of congenitally missing teeth in the mandible was statistically higher than in the maxilla $(p<0.05)$. However, there was no significant difference in the number of congenitally missing teeth between left and right dentitions $(p>0.05)$. Excluding the Mn. third molars, the most frequent congenitally missing teeth site was the Mn. second premolars. In contrast, the most infrequent congenitally missing teeth sites were the Mx. and Mn. first premolars, and Mx. central incisors. The bilateral combination or antagonistic quadrants combination of congenitally missing teeth in hypodontia patients was $80.3 \%$.

The result of this study will contribute to clinicians to make accurate diagnosis and establish favorable treatment plans, by offering invaluable data about the number and distribution of congenitally missing teeth.

Key words : Hypodontia, Missing teeth, Prevalence, Distribution, Oligodontia

\section{I. 서 론}

선천적인 치아결손(Congenitally missing teeth)은 어린이 에서 가장 흔한 발육 장애 중 하나이며 심미와 기능에 영향을 미칠 수 있는 중요한 발육장애로서, 독립적으로 발생하거나 혹 은 다른 증후군에서 나타나는 증상의 일부분으로서 발생할 수 있다 ${ }^{1.2)}$. 결손된 치아 수에 따라 용어가 다른데, 치아결손증 $\left(\mathrm{hy}^{-}\right.$ podontia)이란 제 3 대구치를 제외하고 영구치의 선천적 치아결 손 수가 1 5개인 경우를 말하며, 부분무치증(oligodontia)이 란 문헌에 따라 다르지만 흔히 제 3 대구치를 제외하고 영구치의 선천적 결손치 수가 6개 이상인 경우를 말한다2.3).

선천적인 치아결손의 원인은 아직 정확히 밝혀지지 않았지 만, 유전적 원인, 국소적 원인, 환경적 원인, 그리고 전신질환
등과 연관되어 나타나는 경우가 많다.4). 특정 치아의 선천적 결 손의 원인이 되는 유전자에는 MSX1, PAX9 등이 보고되고 있 다. PAX9 유전자의 변이는 두개악안면과 사지의 변형, 종상기 에서의 치아 성장 정지, 상 - 하악 제 2 대구치 및 제 3 대구치의 선천적 결손과 관련되어 있다. MSX1은 여러 조직의 발육에 참 여하기 때문에 master regulatory gene이라고도 불리며, 이 유전자의 변이는 2 차 구개열, 상 - 하악 치조제 결손, 종상기와 모상기에서의 치아발육장애, 상 - 하악 제 2 소구치, 상악 제 1 소 구치 결손과 관련되어 있다.6.6. Parkin 등근 선천성 치아 결손 의 국소적 원인으로 치판의 생리적 파괴, 맹출공간 부족, 치성 상피의 기능이상, 치성 상피-간질유도의 실패 등을 언급하였다. 선천성 치아결손을 유발하는 환경적 요인으로는 외상, 화학 요 법, 방사선 치료 등이 언급되고 있닥. 전신적인 질환과 연관되

Corresponding author : Jaegon Kim

Department of Pediatric Dentistry and Institute of Oral Bioscience, School of Dentistry, Chonbuk National University, 634-18 Keumam-dong, Deokjin-Gu, Jeonju, 561-180, Korea

Tel: +82-63-250-2128 / Fax: +82-63-250-2131 / E-mail: pedodent@chonbuk.ac.kr

Received September 27, 2013 / Revised October 24, 2013 / Accepted October 24, 2013 
어 선천성 치아결손이 발생할 수 있는데, 대표적인 것으로 외배 엽 형성이상, 연골외배엽 형성이상, 다운증후군, 구개구순열 등 이 알려져 있다 ${ }^{7}$.

다수의 치아상실은 영양의 불균형, 저작기능 상실, 악골 발육 감소, 수직고경 상실, 발음 이상, 비심미적인 안모, 측두 하악관 절의 변위 등의 문제점들뿐만 아니라 심리적인 장애를 야기할 수 있다. 그러므로 임상검사와 방사선 검사를 통한 조기 진단이 필요하며, 치료 시에는 소아치과, 교정과, 보철과, 구강외과의 협진이 필요하다 ${ }^{8)}$.

치아결손증의 유병률은 문헌들에서 다양하게 보고되는데, 치 아결손증은 대개 $1.6 \sim 9.6 \%$, 다수치아가 결손된 부분무치증 역시 0.08 1.1\%로 매우 다양하게 조사되었는데, 이러한 차이 는 환자선정과 조사방법의 차이, 연령, 성별, 인종적 기원의 차 이 때문으로 보고되고 있다. 치아결손증의 유병률은 남자보다 여자에서 더 높고, 상악과 하악에서 비슷한 빈도로 발생한다고 보고되고 있다 ${ }^{9}$. 제 3 대구치를 제외하고 가장 흔한 결손치는 상 악 측절치와 하악 제 2 소구치로 보고되고 있다 ${ }^{10)}$. 치아결손증의 유병률에 대한 조사는 여러 나라에서 실시되어 왔으며, 우리나 라에서도 치아결손증 환자들에 대한 유병률은 조사되고 있지만 교정환자 집단을 대상으로 한 역학조사여서, 일반적인 아동 집 단을 대상으로 한 체계적인 역학조사가 이루어지지 않고 있다.

이 연구의 목적은 전북대학교병원 소아치과에 내원한 7세 $\sim 15$ 세의 환자들 중 제 3 대구치를 제외하고 영구치의 선천적 결 손치를 갖는 환자를 대상으로 하여 치아결손증의 유병률과 선 천적 결손치의 분포를 조사하고자 함이다.

\section{II . 연구 대상 및 방법}

이 연구는 전북대학교병원의 임상 연구 윤리 위원회 (Institutional Review Board, IRB)의 지침에 따라 수립하였 으며, 심의 절차 과정을 통과하였다(IRB번호 : 2013-06-003002).

\section{1. 연구 대상}

이 횡단적 연구는 2008년 1월부터 2012년 12월까지 전북대 학교병원 소아치과에 내원한 7 세에서 15 세 사이 연령의 환자들 중, 파노라마방사선사진을 촬영한 3302명 (남자 1826명, 여자 1476 명)의 소아 환자들을 대상으로 하였다. 제 3 대구치를 제외 하고 영구치 치관의 경조직형성이 가장 늦게 형성되는 제 2 대구 치의 법랑질 완성시기인 7 세를 기준으로 하였고, 제 1,2 소구치 와 제 2 대구치 치배의 결손 여부 파악이 힘들기 때문에 전반적 인 치아 발육, 즉 치령이 정상에서 2년 이상 늦은 경우와 치아 결손증이 강하게 의심되지만 협조가 안 되는 장애인, 치아결손 증과 관련 있는 것으로 밝혀진 전신질환자는 조사 대상에서 제 외시켰다.

\section{2. 연구 방법}

이전의 몇몇 연구에서 영구치 개수의 이상을 진단하는데 신 뢰할만한 방법으로 고려되어진 파노라마방사선사진을 이용하여 영구치배의 선천적 결손 유무를 관찰하였다. 이 연구가 회귀적 이고 한국 아동에서의 치아결손증의 현상을 알아보고자 하였기 때문에 내원 환자들 중 외국인은 배제하였다.

선천적으로 결손된 치아의 정의는 구강내로 맹출하지 않고 방사선 상 치조골 내 석회화가 진행된 부분이 존재하지 않고 발 치의 증거가 없는 경우를 말한다. 소구치들이 석회화의 개시에 큰 변이를 보이기 때문에, 위양성 (false positive) 진단을 피하 기 위해 7 세 이후를 선천적으로 결손된 치아의 평가 연령으로 정하였다.

또한, 부분무치증에 대한 명확한 정의가 내려져 있지 않아, 선천적 결손치 수에 따라 치아결손증과 부분무치증 환자들을 각각의 그룹으로 분류하지 않고 선천적 결손치가 있는 모든 환 자들을 치아결손증 환자들로 간주하고 연구를 수행하였다.

1) 치아결손증(hypodontia)의 유병률

치아결손증의 성별에 따른 유병율을 조사한다. 치아결손증 집단 전체에서 성별, 악궁에 따른 선천적 결손치 수의 차이를 분석하고, 악궁 내에서 좌측과 우측의 선천적 결손치 수의 차이 를 분석하였다.

2) 치아결손증 환자들에서 선천적 결손치의 분포 치아결손증 환자들에서 선천적 결손치가 높게 분포하고 있는 부위와 낮게 분포하는 부위를 조사하였다.

3) 선천적 결손치의 악궁 내 대칭성 혹은 악궁 간 대칭성 평가 치아결손증 환자들에서 선천적 결손치의 악궁 내 대칭성 $\left(\mathrm{bi}^{-}\right.$ lateral combination), 악궁 간 대칭성(antagonistic quadrants combination) 정도를 평가하였다. 악궁 내 대칭성은 같 은 악궁 내에서 좌측과 우측의 동일 부위의 결손이 발생한 경우 를 말하며, 악궁 간 대칭성은 상악과 하악에서 편측의 동일 부 위에 결손이 발생한 경우를 말한다.

4) 관찰자 내 신뢰도

관찰자 내 신뢰도를 평가하기 위해 연구대상 중 330 명 환자 들의 파노라마방사선사진에 대한 검사를 2 번에 걸쳐 측정하였 다. Cohen kappa coefficient를 이용하여 관찰자 내 신뢰도를 평가한 결과, 치아결손증의 유병률에 대한 관찰자 내 일치도는 0.938으로 매우 높게 나타났으며, 치아결손증 환자들에서 결손 치의 개수와 위치에 대한 관찰자 내 일치도는 0.778 로 중등도 이상의 신뢰도를 보였다.

5) 통계적인 분석

파노라마방사선사진으로부터 측정된 자료는 SPSS 19 (SPSS Inc., Chicago, IL, USA)을 이용하여 통계 분석을 실 
시하였다. 전체 모집단에서 상/하악 간 평균 선천적 결손치 수 비교, 우측과 좌측의 평균 선천적 결손치 수 비교, 성별에 따른 상/하악 간 평균 선천적 결손치 수 비교, 성별에 따른 우측과 좌 측의 선천적 결손치 수 비교는 paired t-test를 이용하여 분석 하였다. 통계 분석의 유의수준은 $p<0.05$ 로 하였다.

\section{III. 연구 성적}

\section{1. 치아결손증의 유병률}

총 3302 명의 환자들 중 남자는 1826 명, 여자는 1476 명이었 다. 그 중, 치아결손증 환자는 남자는 108 명 $(5.9 \%)$ 이었고, 여 자는 70 명 $(4.7 \%)$ 으로 남자가 여자보다 약간 높은 유병률을 나 타냈다(Table 1). Table 2에서는 치아결손증 내에서 결손치가

Table 1. Prevalence of hypodontia

\begin{tabular}{ccccccc}
\hline & $\begin{array}{c}\text { Male } \\
(\mathrm{n}=1826)\end{array}$ & $\%$ & $\begin{array}{c}\text { Female } \\
(\mathrm{n}=1476)\end{array}$ & $\%$ & $\begin{array}{c}\text { Total } \\
(\mathrm{n}=3302)\end{array}$ & $\%$ \\
\hline Hypodontia & 108 & 5.9 & 70 & 4.7 & 178 & 5.4 \\
\hline
\end{tabular}

$1 \sim 5$ 개인 경우와 6 개 이상인 경우를 분류하여 선천적 결손치의 개수에 따른 환자들의 분포를 보여주고 있다. 선천적 결손치가 1 개 또는 2 개인 경우가 $66.9 \%$ 로 높은 비율을 차지하며 6 개 이 상의 선천적 결손치가 있는 경우가 치아결손증 환자의 $16.9 \%$ 를 차지하고 있다.

\section{2. 상/하악 간 평균 선천적 결손치 수 비교}

1 개 이상의 선천적 결손치를 가진 178 명의 모집단 전체에서 상악과 하악에서의 선천적 결손치의 차이를 살펴보기 위해 paired t-test를 실시하였다. 그 결과 상악 $(1.37 \pm 1.96)$ 보다 하악(1.76 \pm 1.85$)$ 에서 평균 선천적 결손치 수가 통계적으로 유의하게 높은 수치를 보였고, 남녀 각각에서도 상/하악에 따른 선천적 결손치 수 차이가 통계적으로 유의한 것으로 나타났다 $(p<0.05$, Table 3).

\section{3. 좌/우측의 평균 선천적 결손치 수 비교}

1 개 이상의 선천적 결손치를 가진 178 명의 환자들에서 우측 과 좌측의 선천적 결손치 수를 비교하기 위해 paired t-test를

Table 2. Distribution according to the number of congenitally missing teeth in hypodontia and oligodontia patients

\begin{tabular}{|c|c|c|c|c|c|c|}
\hline & $\begin{array}{c}\text { Male } \\
(\mathrm{n}=108)\end{array}$ & $\%$ & $\begin{array}{l}\text { Female } \\
(\mathrm{n}=70)\end{array}$ & $\%$ & $\begin{array}{c}\text { Total } \\
(\mathrm{n}=178)\end{array}$ & $\%$ \\
\hline \multicolumn{7}{|l|}{ Hypodontia } \\
\hline 1 & 44 & 24.7 & 35 & 19.6 & 79 & 44.3 \\
\hline 2 & 28 & 15.7 & 16 & 9.0 & 44 & 24.7 \\
\hline 3 & 7 & 3.9 & 4 & 2.2 & 11 & 6.1 \\
\hline 4 & 4 & 2.2 & 8 & 4.5 & 12 & 6.7 \\
\hline 5 & 1 & 0.6 & 1 & 0.6 & 2 & 1.2 \\
\hline Sub-total & 84 & 47.2 & 64 & 35.9 & 148 & 83.1 \\
\hline Prevalence & $84 / 1826$ & 4.6 & $64 / 1476$ & 4.3 & $148 / 3302$ & 4.5 \\
\hline \multicolumn{7}{|l|}{ Oligodontia } \\
\hline 6 & 4 & 2.2 & 2 & 1.1 & 6 & 3.3 \\
\hline 7 & 3 & 1.7 & 1 & 0.6 & 4 & 2.2 \\
\hline 8 & 4 & 2.2 & 0 & 0 & 4 & 2.2 \\
\hline 9 & 3 & 1.7 & 0 & 0 & 3 & 1.7 \\
\hline 10 & 1 & 0.6 & 0 & 0 & 1 & 0.6 \\
\hline 11 & 1 & 0.6 & 1 & 0.6 & 2 & 1.1 \\
\hline 12 & 2 & 1.1 & 2 & 1.1 & 4 & 2.2 \\
\hline 13 & 1 & 0.6 & 0 & 0 & 1 & 0.6 \\
\hline 14 & 1 & 0.6 & 0 & 0 & 1 & 0.6 \\
\hline 15 & 1 & 0.6 & 0 & 0 & 1 & 0.6 \\
\hline 16 & 0 & 0 & 0 & 0 & 0 & 0 \\
\hline 17 & 1 & 0.6 & 0 & 0 & 1 & 0.6 \\
\hline 18 & 1 & 0.6 & 0 & 0 & 1 & 0.6 \\
\hline 19 & 1 & 0.6 & 0 & 0 & 1 & 0.6 \\
\hline Sub-total & 24 & 13.5 & 6 & 3.4 & 30 & 16.9 \\
\hline Prevalence & $24 / 1826$ & 1.3 & $6 / 1476$ & 0.4 & $30 / 3302$ & 0.9 \\
\hline Total & 108 & 60.7 & 70 & 39.3 & 178 & 100.0 \\
\hline Prevalence & $108 / 1826$ & 5.9 & $70 / 1476$ & 4.7 & $178 / 3302$ & 5.4 \\
\hline
\end{tabular}


Table 3. Congenitally missing teeth on Maxilla and Mandible on 178 patients

\begin{tabular}{|c|c|c|c|c|}
\hline & Maxilla & Mandible & \multirow{2}{*}{$t$-value } & \multirow{2}{*}{$p$-value } \\
\hline & Mean \pm SD & Mean \pm SD & & \\
\hline Average of congenitally missing teeth(total) & $1.37 \pm 1.96$ & $1.76 \pm 1.85$ & $-3.600 *$ & $0.000^{*}$ \\
\hline Average in male $(\mathrm{n}=108)$ & $1.62 \pm 2.23$ & $1.96 \pm 2.14$ & $-2.200^{*}$ & $0.030^{*}$ \\
\hline Average in female $(\mathrm{n}=70)$ & $0.97 \pm 1.38$ & $1.46 \pm 1.26$ & $-3.287^{*}$ & $0.002 *$ \\
\hline
\end{tabular}

paired t-test, significant at $p<0.05$ level $(*)$

Table 4. Congenitally missing teeth on right and left dentition

\begin{tabular}{lcccr}
\hline & Right(n=178) & Left(n=178) & \multirow{2}{*}{$t$-value } & $p$-value \\
\cline { 2 - 3 } & Mean \pm SD & Mean \pm SD & & 1.075 \\
Average of congenitally missing teeth & $1.61 \pm 1.83$ & $1.52 \pm 1.84$ & 0.284 & 0.615 \\
Average in male & $1.82 \pm 2.13$ & $1.76 \pm 2.07$ & 0.540 & 0.985 \\
Average in female & $1.27 \pm 1.19$ & $1.16 \pm 1.34$ & 0.328 & 0.985 \\
\hline
\end{tabular}

paired t-test, significant at $p<0.05$ level $(*)$

Table 5. Distribution of congenitally missing teeth in hypodontia patients

\begin{tabular}{|c|c|c|c|c|c|}
\hline \multicolumn{2}{|c|}{ Distribution of hypodontia } & Right & Left & Total & Prevalence \\
\hline \multirow{8}{*}{ Maxilla } & Central Incisor & 2 & 2 & 4 & 0.7 \\
\hline & Lateral Incisor & 29 & 28 & 57 & 10.3 \\
\hline & Canine & 18 & 15 & 33 & 5.9 \\
\hline & 1st Premolar & 20 & 20 & 40 & 7.2 \\
\hline & 2nd Premolar & 45 & 42 & 87 & 15.6 \\
\hline & 1st Molar & 2 & 2 & 4 & 0.7 \\
\hline & 2nd Molar & 10 & 8 & 18 & 3.2 \\
\hline & Total & 126 & 117 & 243 & 43.6 \\
\hline \multirow{8}{*}{ Mandible } & Central Incisor & 28 & 22 & 50 & 9.0 \\
\hline & Lateral Incisor & 26 & 21 & 47 & 8.5 \\
\hline & Canine & 8 & 10 & 18 & 3.2 \\
\hline & 1st Premolar & 15 & 15 & 30 & 5.4 \\
\hline & 2nd Premolar & 73 & 76 & 149 & 26.8 \\
\hline & 1st Molar & 2 & 2 & 4 & 0.7 \\
\hline & 2nd Molar & 8 & 7 & 15 & 2.7 \\
\hline & Total & 160 & 153 & 313 & 56.4 \\
\hline
\end{tabular}

실시하였다. 그 결과 우측 $(1.61 \pm 1.83)$ 이 좌측 $(1.52 \pm 1.84)$ 보다 선천적 결손치 수가 많았지만, 통계적으로 유의하게 나타 나지는 않았다. 남녀 각각의 그룹에서도 우측과 좌측 간 평균 선천적 결손치 수 차이가 통계적으로 유의하지 않은 것으로 나 타났다 $(p>0.05$, Table 4$)$.

\section{4. 선천적 결손치의 악궁 내 분포}

치아결손증 그룹에서, 선천적 결손치의 악궁 내 분포는 Table 5에 나와 있다. 선천적 결손치가 가장 많이 분포하는 부 위는 하악 제 2 소구치였으며, 상악 제 2 소구치, 상악 측절치, 하 악 중절치 순으로 높게 분포하고 있었다. 반대로, 치아결손증 그룹 148 명에서 선천적 결손치가 가장 적게 분포하는 부위는 상 - 하악 제 1 대구치, 상악 중절치였으며, 하악 제 2 대구치, 상
악 제 2 대구치, 하악 견치 순으로 낮게 분포하였다.

\section{5. 선천적 결손치의 성별에 따른 분포}

치아결손증 그룹에서 선천적 결손치의 성별에 따른 분포는 Table 6에 나와 있다. 남녀에서 선천적 결손치가 낮게 분포하 고 있는 부위는 대체로 비슷하였으나 순서의 차이를 보이는데, 남자에서는 상악 중절치, 상 - 하악 제 1 대구치, 상 - 하악 제 2 대 구치, 하악 견치 순으로 낮게 분포하는 반면, 여자에서는 상 하악 제 1 대구치, 상악 중절치, 하악 제 2 대구치, 하악 견치, 상 악 제 2 대구치 순으로 낮게 분포하였다. 남녀에서 선천적 결손 치가 높게 분포하고 있는 부위는 남녀 모두에서 하악 제 2 소구 치, 상악 제 2 소구치, 상악 측절치, 하악 중절치, 하악 측절치, 상악 제 1 소구치 순으로 높게 분포하였다. 
Table 6. Sex distribution of congenitally missing teeth in hypodontia patients

\begin{tabular}{lcccc}
\hline \multirow{2}{*}{ Teeth } & \multicolumn{2}{c}{ Male $(\mathrm{n}=108)$} & \multicolumn{2}{c}{ Female $(\mathrm{n}=70)$} \\
\cline { 2 - 5 } & Maxilla(\%) & Mandible(\%) & Maxilla(\%) & Mandible(\%) \\
\hline Central Incisor & $3(0.8)$ & $33(8.5)$ & $1(0.6)$ & $17(10.0)$ \\
Lateral Incisor & $38(9.8)$ & $32(8.3)$ & $19(11.2)$ & $15(8.8)$ \\
Canine & $27(7.0)$ & $14(3.6)$ & $6(3.5)$ & $4(2.4)$ \\
1st Premolar & $32(8.3)$ & $22(5.7)$ & $8(4.7)$ & $8(4.7)$ \\
2nd Premolar & $58(15.0)$ & $94(24.3)$ & $29(17.1)$ & $55(32.4)$ \\
1st Molar & $4(1.0)$ & $4(1.0)$ & $0(0.0)$ & $0(0.0)$ \\
2nd Molar & $13(3.4)$ & $13(3.4)$ & $5(2.9)$ & $3(1.8)$ \\
Sub-total & $175(45.2)$ & $212(54.8)$ & $68(40.0)$ & $102(60.0)$ \\
Total & \multicolumn{2}{c}{$387(3.58$ per child) } & $170(2.43$ per child) \\
\hline
\end{tabular}

Table 7. Distribution of symmetrical and non-symmetrical pattern of missing teeth in total congenitally missing teeth

\begin{tabular}{lcccccc}
\hline & Bilateral combinations & $\%$ & Antagonistic quadrants combinations & $\%$ & Unilateral teeth & $\%$ \\
\hline Total missing teeth $(\mathrm{n}=557)$ & 394 & 70.7 & 254 & 45.6 & 110 & 19.7 \\
\hline
\end{tabular}

6. 선천적 결손치의 악궁 내 대칭성(Bilateral combinations), 악궁 간 대칭성(antagonistic quadrants combinations) 평가

치아결손증 환자 178 명에서 분포하고 있는 557 개의 선천적 결손치에 대한 대칭성 평가에서, 악궁 내 대칭성은 $70.7 \%$ 로 높 은 비율을 보이고 있고, 악궁 간 대칭성은 $45.6 \%$, 독립적 (unilateral)으로 발생한 경우는 $19.7 \%$ 로 나타났다(Table 7). 악 궁 내 대칭성에 해당되면서 동시에 악궁 간 대칭성에 해당되는 치아(200개, $35.9 \%)$ 도 다수 존재하였다.

\section{$\mathrm{IV}$. 총괄 및 고찰}

선천적인 치아결손이 흔한 치아발육장애 중 하나이기 때문 에, 영구치의 치아결손증에 대한 많은 연구들이 지난 50년간 치과적 문헌을 통해 보고되어왔다 ${ }^{7.9}$. 이 연구에서 조사 방법은 영구치 개수의 이상을 진단하는데 가장 신뢰할만한 방법으로 고려되는 파노라마방사선사진을 이용하여 시행되었다. 이전의 몇몇 연구에서는 임상적인 검사방법만을 이용하였는데, 이러한 방법은 파노라마방사선사진을 통한 방법보다 영구치 선천적 결 손치 개수를 정확히 평가할 수 없다 ${ }^{11}$. Terasaki 등 ${ }^{18}$ 의 연구에 의하면 임상적 관찰만으로는 실제 결손치의 $70 \%$ 정도만 진단이 가능하다고 하였다. 더욱이, 선천적 결손치가 구강 내로 맹출에 실패하고 방사선 상 식별이 가능하지 않은 치아로 정의되기 때 문에, 선천적으로 결손된 영구치의 진단에 있어 방사선검사는 필수적이라고 말할 수 있다.

이 연구에서 치아결손증의 유병률은 남자에서 $5.9 \%$, 여자에 서 $4.7 \%$ 로 남자가 여자보다 약간 높은 유병률을 나타냈는데, 이는 대부분의 문헌들에서 여자가 남자보다 치아결손증의 유병
률이 높거나 아니면 성별에 따른 유의한 유병률 차이는 없다는 기존의 연구들과 상반된다 ${ }^{1,13.14)}$. 6 개 이상의 선천적 결손치를 가진 부분무치증의 경우에서 부분무치증의 남녀의 유병률은 남 자가 여자보다 3 배 이상 높은 유병률을 보였다. 이는 치아결손 증을 일으키는 병인 중 주요한 원인인 유전적 요소 이외에 다른 요소들, 예를 들면 인종적, 환경적 요소 등이 복합적으로 작용 했을 가능성이 있고, 이에 대한 향후의 추가적인 병인론적 연구 가 필요할 것으로 판단된다.

이 연구가 이전의 다른 연구들과 일치하는 점은 치아결손증 에서 1 개 또는 2 개의 선천적 결손치를 갖는 경우가 대부분을 차지하는데 ${ }^{18.19)}$, 이 연구에서도 $69.0 \%$ 로 높은 비율을 차지한 다. 그러므로, 선천적 결손치를 갖는 환자들의 상당수는 경미한 치아결손증을 갖고 있다고 말할 수 있다.

이전의 몇몇 연구들은 선천적 결손치를 갖는 환자들에서 선천 적 결손치의 대칭성이 뚜렷이 나타난다는 것을 제시해왔다1.14). 악궁 내 대칭적 (bilateral)이거나 악궁 간 대칭적(contralateral)인 비율은 연구들마다 약간씩 차이가 있는데, Silva 등1ㅣ 에 의한 멕시코인에 대한 연구에서는 $75 \%$, Bergstom 등 21 에 의 한 노르웨이인에 대한 연구에서는 $60 \%$, Endo 등 22 에 의한 일 본인에 대한 연구에서는 $89 \%$ 로 나타났는데, 선천적 결손치가 강한 유전적 영향을 받음을 제시하고 있다. 이 연구에서의 악궁 내 대칭성, 악궁 간 대칭성은 각각 $70.7 \%, 45.6 \%$ 로 나타났고 독립적으로 발생한 경우는 $19.7 \%$ 로 나타났다. 이 논문의 결과 에 나와 있지 않으나 6 개 이상의 선천적 결손치를 갖는 환자들 에서 악궁 내 대칭성 혹은 악궁 간 대칭성은 $92 \%$ 로 매우 높게 나타났다. 1 개의 선천적 결손치를 갖는 79 명을 제외할 경우 악 궁 내 대칭성 또는 악궁 간 대칭성은 $94.4 \%$ 로 매우 높음을 분 석할 수 있고, 이로부터 선천적으로 결손된 영구치들에서 강한 유전적 영향이 있음을 알 수 있다. 
이전의 많은 연구들에서는 성별에 따른 평균 선천적 결손치 수의 차이가 거의 없음을 보여주었는데 ${ }^{21.26 .29)}$, 이 연구에서는 이 전의 연구들과는 다르게 평균 선천적 결손치 수가 남자에서는 3.58 개, 여자에서는 2.43 개로 남자에서 훨씬 높음을 알 수 있 다. 이것은 남자에서 6 개 이상 선천적 결손치의 상대적 비율이 여자에서의 상대적 비율보다 훨씬 높아, 남자 집단에서의 평균 선천적 결손치 개수를 증가시켰을 것으로 생각된다. 다른 기존 연구들9)과 일치하게도 이 연구에서, 하악에서의 선천적 결손치 수는 상악보다 더 많고 통계적으로 유의한 차이를 나타내었고 남자와 여자 각각의 그룹에서도 하악의 선천적 결손치가 상악 보다 통계적으로 유의하게 높은 수치를 보여주었다.

제 1 대구치는 가장 안정적인 치아로서 치아결손증의 유병률에 관한 몇몇 보고에서는 상 - 하악 제 1 대구치가 한 명도 이환되지 않았다는 것과 상악 중절치와 하악 견치 또한 매우 드물게 결손 됨을 보고하였다 ${ }^{9}$. 이 연구에서도 이전의 연구들과 유사하게 상 - 하악 제 1 대구치 $(0.7 \%)$, 상악 중절치 $(0.7 \%)$ 에서 결손치가 거의 분포하지 않았으며, 하악 제 2 대구치 $(2.7 \%)$, 상악 제 2 대 구치 (3.2\%), 하악 견치 $(3.2 \%)$ 순으로 낮게 분포하였다.

이전의 연구들에서 보면, 치아결 손증의 유병률은 $1.44 \sim 15.9 \%$ 로 다양하게 보고되었으며, 대부분의 연구들에서 제 3 대구치를 제외하고 가장 흔하게 결손되는 치아는 하악 제 2 소구치, 상악 측절치, 상악 제 2 소구치 순으로 보고되었다 ${ }^{1.9)}$. 그 러나, 아시아인을 대상으로 한 연구에서는 경향이 다른데, 중국 인을 대상으로 한 연구에서는 선천적 결손치의 $60 \%$ 정도가 하 악 절치였고, 일본인을 대상으로 한 연구들에서는 하악 측절치 가 가장 결손 빈도가 높다고 나온 경우도 있었고 상악 측절치가 가장 결손 빈도가 높게 나온 경우도 있었다 ${ }^{1}$. 이 연구에서도 가 장 흔하게 결손되는 치아는 하악 제 2 소구치 $(26.8 \%)$ 로 매우 높 은 비율을 보였으며, 그 다음으로 상악 제 2 소구치 $(15.6 \%)$, 상 악 측절치 $(10.3 \%)$, 하악 중절치 $(9.0 \%)$ 순으로 높게 분포하여 이전의 연구들과 약간의 차이가 있었다. 이 연구결과에 나와 있 지 않지만 특이할 만한 점은 6 개 미만의 치아결손증 집단의 258 개의 선천적 결손치 중 상 - 하악 제 1 소구치 부위는 각각 3 개씩 $(1.2 \%)$ 이었지만, 6 개 이상의 선천적 결손치를 갖는 집단 에서는 총 299 개의 선천적 결손치 중 상악 제 1 소구치는 37 개 (12.4\%), 하악 제 1 소구치는 27 개(9.1\%)로 상악 측절치 (9.1\%)보다 높거나 비슷한 분포를 보였다. 이런 점으로 볼 때 상 - 하악 제 2 소구치와 상악 측절치는 선천적 결손치의 개수에 따라 상관없이 높은 결손률을 보이는 반면, 상 - 하악 제 1 소구 치는 결손치 개수가 증가할수록 상대적으로 높은 결손률을 보 인다고 할 수 있다.

치아결손증에 대한 유병율 연구는 다음의 3가지 약점을 갖고 있다. 첫째, 이런 종류의 연구 진행 시 연령이 중요한 문제이기 때문에 연령에 기반한 제외 기준이 반드시 도입되어야 한다. 방 사선학적으로 치배의 시각화는 치아의 광화단계에 의존적이고, 같은 연령 그룹에서도 광화 단계와 치령간의 많은 차이가 존재 한다는 것을 아는 것은 중요하다. 광화가 늦게 시작하는 치배, 특히 하악 제 2 소구치는 방사선 영상에서 치아 무형성 (agene- sis)에 대한 위양성(false-positive) 진단을 초래할 수 있다. 일 반적으로 영구치열에서 치아 무형성에 대한 진단은 제3대구치 를 제외할 때 6세 이후, 제3대구치를 포함한다면 10세 이후에 이루어져야 한다. 그러므로, 7 세 이전의 아이들에서 위양성 진 단을 피하기 위해 소구치 부위에서의 특별한 주의가 필요된다.9). 이 연구에서도 위양성 진단을 피하기 위해 만 7세 이후의 소아 환자들을 대상으로 하였고, 그룹 내 상대적으로 낮은 연령에서 소구치 부위의 결손 시 다른 치아의 발육정도, 영구치열의 발육 연령, 방사선학적으로 치아가 시각화되는 대략적인 연령에 대한 기준들에 관한 자료들을 종합적으로 고려하여 진단을 내렸다.

둘째, 하악 중절치와 하악 측절치의 결손을 구분하는 것이 흔 히 어려울 수 있는데, 특히 주변 치아들이 결손된 부위로 이동 했을 경우 구분하기 어렵달). 그렇기 때문에 이 치아들 간에 잘 못 분류되는 경우가 종종 발생하는데, 일부 연구들에서는 하악 측절치의 결손률이 더 높게 관찰된 반면1.5), 또 다른 연구들에서 는 하악 중절치의 결손률이 더 높게 관찰되었다 ${ }^{13,14,16)}$. 또한, 일 부 연구에서는 하악 절치들로서 그룹을 만들어 조사하기도 하 였다 ${ }^{11}$. 본 연구 수행 시 역시 이러한 문제점이 나타났는데, 치 아결손증 그룹에서도 남자에서는 하악 측절치가 하악 중절치보 다 결손치 비율이 높았고, 여자에서는 하악 중절치가 하악 측절 치보다 결손치 비율이 높았다. 이 연구에서 관찰자 내 일치도를 평가할 때도, 하악 절치부에서의 불일치가 대부분을 차지하였다.

셋째, 또 하나의 변수는 조사된 집단의 인종이고, 이것은 결 과에 영향을 미칠 수 있다. 문헌들에서는 어떤 치아들이 흔하게 결손 되는지에 대해 부분적으로는 인종적 차이에서 비롯된 것 이라고 설명하고 있다 ${ }^{27}$. 스웨덴과 일본인을 대상으로 한 연구 에서, 하악 중절치는 다른 인종 집단에서보다 더 흔하게 결손됨 을 보여주었다 ${ }^{19}$. 다른 연구들에서는 치아결손증이 아시아인과 미국 원주민들에서 더욱 흔하고, 유럽 그리고 호주의 코카시안 집단에서의 치아 무형성의 유병률이 북미 코카시안 집단보다 더 높음을 보고하였다 ${ }^{9}$.

많은 가족 증례보고들과 쌍둥이들에 대한 연구를 통해 치아 결손증의 병인에 대한 몇 가지 설명들이 진행되어 왔다 ${ }^{25)}$. 비록 정확한 유전적 메카니즘이 완전하게 이해되지는 않았지만, 치 아결손증은 유전적 특징을 갖는 것처럼 보인다. 한 가지 설명은 유전적인 경우가 아닌 선천적 치아결손증의 경우, 치배의 발육 이 다른 주변 부위보다 늦고 이환치에 해당하는 공간이 뚜렷하 게 부족할 가능성이 높다는 것이다 ${ }^{27)}$. 치아결손증 환자들에서, 파노라마방사선사진을 통한 분석 시 측모두부규격방사선사진 촬영 비율이 $10 \sim 15 \%$ 정도로 비교적 높았던 것은 다른 치아발 육 및 형태 이상, 골격적 문제를 동반한 교정적 문제가 있었을 것으로 판단할 수 있다.

Jorgenson 등'2)은 치아결손증의 유병률이 시간이 지남에 따 라 증가한다는 점을 언급하였다. 사실, 측절치, 제 2 소구치, 제 3 대구치는 이 연구를 포함하여 여러 논문에서 선천적 결손치가 특히 많이 발생하는 부위이다. 게다가, 치아 크기 감소와 치아 발육 지연이 치아결손증 그룹의 어린이들에서 관찰되고 있다. 이러한 두 발견들은 Bolk에 의해 제안된 각 치아 유형의 가장 
후방부 치아에 대한 'Terminale Reduction' 이론에서의 주장 들과 일치된다 ${ }^{8)}$.

종종 각 치아 관련 비정상의 병인은 독립적인 것으로 고려되 지만, 그것들 중 일부는 서로 연관성이 있는 것으로 보인다. 치 아결손증과 왜소치는 높은 상관관계를 갖고, 심도에 따라 증가 한다 ${ }^{21)}$. $\mathrm{Brook}^{30}$ 의 제안에 따르면, 유전적 요소와 환경적 요소 는 서로 독립적인 것이 아니라, 두 요소의 결합된 효과의 결과 로서 치아결손증이 발생한다고 하였다.

제3대구치의 존재는 교정치료를 계획하는 것에 대한 생역학 적 고려사항과 전반적인 치료 안정성에 영향을 미칠 수 있다. 특별히, 치아결손증이 있는 환자들에서 제 3 대구치는 선천적 결 손치에 대한 대체 수단으로서 교합 내로 배열될 수 있다. Chung 등5)의 우리나라 소아환자들을 대상으로 한 연구에서는, 불행히도 치아결손증 환자들 중 $48.2 \%$ 에서 제 3 대구치의 선천 적 결손이 있었고, 이것은 치아결손증이 없는 환자들에서의 결 손률 $(27.4 \%)$ 과 비교하여 통계적으로 유의하게 높았고, 제 3 대 구치의 선천적 결손은 치아결손증과 강한 상관관계가 있다고 말할 수 있다.

치아결손증이 유치열보다는 영구치열에서 흔하게 영향을 미 치고, 기능적 장애 및 심미적 문제를 야기할 수 있기 때문에, 가 능한 한 일찍 장애를 인지하는 것이 중요하고, 여러 과의 협진 을 통한 관리가 필요하다. 그러므로, 우리의 연구결과는 임상의 에게 선천적 결손치의 수와 위치에 대한 가치 있는 정보를 제공 하여 정확한 진단을 내리고 바람직한 치료계획을 수립하는데 기여할 것이다.

\section{V. 결 론}

2008년 1월부터 2012년 12월까지 소아치과에 내원한 7 15세 사이 아동 중, 파노라마방사선사진을 촬영한 3302명 을 대상으로 하여 치아결손증의 유병률 및 선천적 결손치 분포 에 대해 분석하여 다음과 같은 결론을 얻었다.

1. 치아결손증 환자 중, 남자는 108 명 $(5.9 \%)$ 이었고, 여자는 70명 (4.7\%)으로 남자가 여자보다 약간 높은 유병률을 나 타냈다. 남자에서 평균 선천적 결손치 개수는 3.58 개였으 며, 여자는 2.43 개였다.

2. 1 개 이상의 선천적 결손치를 가진 178 명의 아동에서, 상 악 $(1.37 \pm 1.96)$ 보다 하악 $(1.76 \pm 1.85)$ 에서 선천적 결손치 수가 통계적으로 유의하게 높은 비율을 보였고 $(p$ $<0.05)$, 남녀 각각의 그룹에서도 상악보다 하악에서 선천 적 결손치 수가 통계적으로 유의하게 높았다 $(p<0.05)$.

3. 역시 178 명의 모집단에서 우측과 좌측치열의 선천적 결손 치 수를 비교하였을 때, 우측( $1.61 \pm 1.83)$ 이 좌측(1.52 $\pm 1.84)$ 간에 통계적으로 유의한 차이가 나타나지 않았고 ( $p>0.05)$, 남녀 각각의 그룹에서도 우측과 좌측간의 선 천적 결손치 수가 통계적으로 유의한 차이를 나타내지 않 았다 $(p>0.05)$.

4. 선천적 결손치가 가장 많이 분포하는 부위는 하악 제 2 소
구치였으며, 상악 제 2 소구치, 상악 측절치, 하악 중절치 순으로 높게 분포하고 있었다. 반대로 선천적 결손치가 가 장 적게 분포하는 부위는 상 - 하악 제 1 대구치, 상악 중절 치였으며, 하악 제 2 대구치, 상악 제 2 대구치, 하악 견치 순 으로 낮게 분포하였다. 상 - 하악 제 1 소구치는 선천적 결 손치가 증가할수록 상대적으로 높은 선천적 결손치 발생 률을 보였다.

5. 치아결손증 환자들에서 선천적 결손치의 악궁 내 대칭성 혹은 악궁 간 대칭성은 $80.3 \%$ 로 매우 높게 나타났고, 1 개 의 결손치를 갖는 환자들을 배제하였을 때 $94.4 \%$ 의 매우 높은 대칭성을 보였다.

\section{References}

1. Harold AG, Shigeo T, Takahide M, et al. : An orthopantomographic study of hypodontia in permanet teeth of Japanese pediatric patients. $J$ Oral Sci, 50:143-150, 2008.

2. Son JM, Choi NK, Kim SM, et al. : Oligodontia : case report. J Korean Acad Pediatr Dent, 34:658665, 2007.

3. Karoline D, Steven S, Koenraad D, et al. : Tooth agenesis patterns and phenotype variation in a cohort of Belgian patients with hypodontia and oligodontia clustered in 79 families with their pedigrees. Eur J Orthod, Advance Access April 18, 2013.

4. Chung CJ, Han JH, Kim KH : The pattern and prevalence of hypodontia in Koreans. Oral Dis, 14: 620-625, 2008.

5. Breno RB, Sergio E : Dentistry and molecular biology : a promising field for tooth agenesis management. Tohoku J Exp Med, 226:243-249, 2012.

6. Sharat CP : The genetic basis of tooth agenesis : basic concepts and genes involved. J Indian Soc Pedod Prev Dent, 29:84-89, 2011.

7. Parkin N, Elcock C, Smith RN, et al. : The aetiology of hypodontia: the prevalence, severity and location of hypodontia within families. Arch Oral Biol, 54: S52-56, 2009.

8. Kim JY, Lee KH, La JY, et al. : Removable flexible denture for children with oligodontia : a case report. J Korean Acad Pediatr Dent, 36:150-156, 2009.

9. Polder BJ, Van't Hof MA, Van der Linden FP, et al. : A meta-analysis of the prevalence of dental agenesis of permanent teeth. Community Dent Oral Epidemiol, 32:217-26, 2004.

10. Silva Meza R : Radiographic assessment of congenitally missing teeth in orthodontics patients. Int $J$ 
Paediatr Dent, 13:112-116, 2003.

11. Jorgenson RJ : Clinician's view of hypodontia. J Am Dent Assoc, 101:283-286, 1980.

12. Yamaguchi T, Tomoyasu Y, Nakadate T, et al. : Allergy as a possible predisposing factor for hypodontia. Eur J Orthod, 30:641-644, 2008.

13. Bartzela TN, Carels CE, Bronkhorst EM, et al. : Tooth agenesis patterns in bilateral cleft lip and palate. Eur J Oral Sci, 118:47-52, 2010.

14. Shafi I, Phillips JM, Dawson MP, et al. : A study of patients attending a multidisciplinary hypodontia clinic over a five year period. Br Dent J, 205:649652, 2008.

15. Worsaae N, Jensen BN, Holm B, et al. : Treatment of severe hypodontia-oligodontia - an interdisciplinary concept. Int J Oral Maxillofac Surg, 36:473480, 2007.

16. Edward F. Harris, Larkin L. et al. : Hypodontia : An epidemiologic study of American black and white people. Am J Orthod Dentofacial Orthop, 134:7617, 2008.

17. Celikoglu M, Kazanci F, Miloglu O, et al. : Frequency and characteristics of tooth agenesis among an orthodontic patient population. Med Oral Patol Oral Cir Bucal, 15:e797-801, 2010.

18. Steen R, Sven P : Agenesis of permanent teeth in 8138 Danish schoolchildren : prevalence and intraoral distribution according to gender. Int $J$ of Paediar Dent, 19:172-175, 2009.

19. Victoria TW, Pekka N, Sirpa A, et al. : An epidemiological study of dental agenesis in a primary health area in Spain : Estimated prevalence and associated factors. Oral Medicine and Pathology, 15:569-74, 2010.

20. Terasaki T, Shiota K : Congenital absence of teeth. Nihon Koku Kagakkai Zasshi, 3:88-93, 1954.

21. Bergström K. : An orthopantomographic study of hypodontia, supernumeraries and other anomalies in school children between the ages of 8-9 years. An epidemiological study. Swed Dent J, 1:145-157, 1977.

22. Endo T, Ozoe R, Kubota M, et al. : A survey of hypodontia in Japanese orthodontics patients. Am J Orthod Dentofacial Orthop, 129:29-35, 2006.

23. Niswander JD, Sujaku C : Congenital anomalies of teeth in Japanese children. Am J Phys Anthropol, 21:569-574, 1963

24. Kreczi A, Proff P, Reicheneder C, et al. : Effects of hypodontia on craniofacial structures and mandibular growth pattern. Head Face Med, 7;23:1-9, 2011.

25. Guala A, Falco V, Breedveld G, et al. : Deletion of PAX9 and oligodontia: a third family and review of the literature. Int $J$ Paediatr Dent, 18:441-445, 2008.

26. Larmour CJ, Mossey PA, Thind BS, et al. : Hypodontia-a retrospective review of prevalence and etiology. Part I. Quintessence Int, 36:263-270, 2005.

27. Créton MA, Cune MS, Verhoeven W, et al. : Patterns of missing teeth in a population of oligodontia patients. Int J Prosthodont, 20:409-13, 2007.

28. Calvano Küchler E, De Andrade Risso P, De Castro Costa M, et al. : Assessing the proposed association between tooth agenesis and taurodontism in 975 paediatric subjects. Int $J$ Paediatr Dent, 18:231234, 2008.

29. Goldenberg M, Das P, Messersmith M, et al. : Clinical, radiographic, and genetic evaluation of a novel form of autosomal-dominant oligodontia. $J$ Dent Res, 79:1469-1475, 2000.

30. Brooks AH : A unifying aetiological explanation or anomalies of human tooth number and size. Arch Oral Biol, 29:373-378, 1984. 
국문초록

전북대학교병원 소아치과에 내원한 어린이에서 선천적으로 결손된 치아의 유병률 및 분포

\author{
전현순·양연미·백병주 · 김재곤
}

전북대학교 치의학전문대학원 소아치과학교실 및 구강생체과학연구소

이 연구는 2008년 1월부터 2012년 12월까지 소아치과에 내원한 7 15세 사이 아동 중, 파노라마방사선사진을 촬영한 3302 명을 대상으로 하여 치아결손증의 유병률 및 선천적 결손치의 분포에 대해 분석하기 위함이었다.

치아결손증의 유병률은 남자 $(5.9 \%)$ 가 여자(4.7\%)보다 약간 높게 나왔으며, 남자에서 평균 선천적 결손치 수는 3.58 개, 여자는 2.43개였다. 평균 선천적 결손치 수는 상악보다 하악에서 통계적으로 유의하게 높은 비율을 보였고 $(p<0.05)$, 좌측 과 우측치열간의 선천적 결손치 수의 차이는 통계적으로 유의하지 않았다 $(p>0.05)$. 선천적 결손치가 가장 많이 분포하는 부위는 하악 제 2 소구치였으며 반대로 선천적 결손치가 가장 적게 분포하는 부위는 상 - 하악 제 1 대구치, 상악 중절치였다. 치 아결손증 환자들에서 선천적 결손치의 악궁 내 대칭성 혹은 악궁 간 대칭성은 $80.3 \%$ 로 높게 나타났다.

이 연구의 결과는 임상의에게 선천적 결손치의 수와 위치에 대한 가치 있는 정보를 제공하여 정확한 진단을 내리고 바람직 한 치료계획을 수립하는데 기여할 것이다.

주요어: 치아결손증, 결손치, 유병율, 분포, 부분무치증 